\title{
Islam Nusantara: A Middle Way?
}

\section{Luqman Nurhisam}

UIN Sunan Kalijaga, Yogyakarta

\begin{abstract}
Islam Nusantara is not a new thing. The word "Islam" combined with "Nusantara" is not only confirmed the name, but also the characters to show the pattern of a heterogeneous entity. The concept of Islam Nusantara face (vis a vis) with Islam in the Middle East (Islam Arab). Diversity as a typology of Islam Nusantara is the result of the struggle that the length between religion and dimensions of life (social, economic, politic, culture and etc.), the text of the context that complement one another so that spawn Islam friendly, peaceful, anti-radical, harmony and rahmatan lil 'alamin. Departing from the historical and epistemological approach, this article tries to provide a long discourse that was raised again in the "Declaration of Nahdlatul Ulama" at the International Conference of Islamic Leaders Moderate (ISOMIL) which took place from 9 to II May in Jakarta. The purpose of writing this article is actually also want to answer the issues pointed out that Islam Nusantara models reflect the teachings of Islam are not singular.
\end{abstract}

\begin{abstract}
Abstrak
Islam Nusantara bukanlah hal yang baru. Kata "Islam” digabungkan dengan "Nusantara” tidak hanya soal nama, tetapi juga karakter yang menunjukkan pola keberagaman. Konsep Islam Nusantara dihadapkan dengan Islam Arab. Keberagaman sebagai tipologi Islam Nusantara adalah hasil dari perjuangan yang panjang antara agama dan dimensi kehidupan (sosial, ekonomi, politik, budaya dan lain-lain), teks konteks yang melengkapi satu dengan lainnya yang menjadikan Islam ramah, damai, anti-radikal, harmonis dan rahmatan lil'alamin. Berangkat dari pendekatan sejarah dan epistemologis, artikel ini berusaha untuk memberikan wacana lama yang dimunculkan kembali pada "Deklarasi Nahdlatul Ulama” pada Konferensi Internasional Pemimpin Islam Moderat (ISOMIL) yang berlangsung pada 9 sampai I I Mei di Jakarta.Tujuan dari penulisan artikel ini sebenarnya juga untuk menjawab isu yang menyebutkan bahwa Model Islam Nusantara mencerminkan ajaran Islam yang tidak tunggal.
\end{abstract}

Keywords: Islam Nusantara \& Islam Arab 


\section{Introduction}

The term of Islam Nusantara has not known exactly when it was come for the first time. However, this term resurfaced in around the beginning of May 2016, and been debated by many academicians. There is one group that says it is a form of heresy, while another group chimed with a concept that is equally telling. They negate each other, on one side considers what he believes is the only truth (single truth) and on the other side considers that it is a unique form of plurality. There is a conflict, especially in terms of understanding Islamic law.

The outcome was the occurrence of socio-religious polemic that became more debatable. A fragment of a long history that has shaped civilization becomes increasingly blurred. In fact, we become blind and difficult to distinguish between the cultural product and the product of religion, even some people may believe to perceive and understand that Arab is not necessarily a sign as a Muslim, and otherwise Islam is not also necessarily a sign of Arab. In this context, some of the people have an understanding Arabsentris that should be Islamsentris. The concern is more on the Muslims seemed to be forgotten that the basic teachings of Islam that is shade, harmony, and love peace on akhlakul kharimah, while the other that is filled with violence, rage, which is always considered to be exclusive, even destructive.

From the problems above, this paper aims to find out the debate which bears the distinction of religious ideas that often occur in Indonesia. On the basis of epistemological and historical framework, this paper seeks to answer questions on what and how is Islam Nusantara?

\section{The Terminology of Islam Nusantara}

According to Akhmad Sahal, to understand Islam Nusantara people must believe into the existence of religious and cultural dimension. This dimension is an Islamic way on how to compromise with borders that have specific cultural roots. The result in Islam entirely has no longer presented them as rigid and closed, but appreciate otherness. Islam is much accommodated the values that are contained within certain territory. This is confirmed also by Gus Dur that, "the overlap between religion and culture will continue to occur continuously as a process that will enrich life and make it barren" (Sahal 2015, 33).

From the above statement, the question then extended to what Islam Nusantara is. Meaning, whether Islam Nusantara, or whether Islam of Nusantara, or is it Nusantara of Islam? It is Islam in Nusantara or Islam that is Nusantara? There is still any ambiguity regarding the term Islam Nusantara itself. If Nusantara is defined as a place or region then called Islam Nusantara must profiteer all schools and Islamic organizations in Indonesia. Islam Nusantara means not merely confined to, or characteristic of The Nahdliyin (NU). Nor vice versa, when 
the Nusantara interpreted as typical values, it means profiteer character and characteristics of Islam in Indonesia in which includes elements of worship mahdah and muamalah.

Furthermore, Mustafa Bisri (Gus Mus) never describes the term of Islam Nusantara. He said that it would be wrong if the intent is understood in the structure of given the nature, which means "Islam brought down to the earth," but it would be right if placed into the structure of idhafah (designation place) which means "Islam in Nusantara". Even though, Gus Mus emphasized that the explanation above is not exactly wrong in the context to dampen fears of a group who has misunderstood on Islam Nusantara. However, it should be understood that the appointment is also a means to uncover the elements that exist in the area. Like it or not, we should still embrace the nature and characteristics of a region called Nusantara.

According to Azyumardi Azra, Islam Indonesia is sustainable to also explain that the term of "Islam Nusantara" in the academic world refers to "Southeast Asian Islam" which is compressing Muslim in the areas of Indonesia, Malaysia, Brunei, Pattani (Southern of Thailand) and Mindanao (Southern of the Philippines). Islam Nusantara region in the precolonial literature called "the land below the wind". More specifically in Arab literature, since the $16^{\text {th }}$ Century Islam Nusantara region called "Bilad al-Jawi" or called as Southeast Asia. The Muslim Ummah Nusantara commonly referred to as "al-Jawiyyin ashab" or "Jama'ah al-Jawiyy". Islam Nusantara region is one of the eight religio-cultural realms of Islam. It is seven realms of religion and culture of Islam other than Arabic, Persian/Iranian, Turkish, Indian subcontinent, Sino Islamic, Black Africa, and the Western World. Despite holding the key principles and teachings of the same in the creed and worship, but each domain has a religious character and its own culture (Azra 2015).

While Teuku Kemal Fasya in one of his writings, Poetic and Cultural Dimensions of Islam Nusantara, explained that Islam Nusantara is the appreciation and practice of the locality's people who live in the archipelago. Legalization of the word "Nusantara" is not simply an affirmation place name or noun, but more importantly, an explanation adjective or quality Islam "here" in contrast to Islam "over there". The successful of Islam in archipelago as peacefully cannot be separated from the adaptability and resilience of knowledge, local arts, and culture belongs to Islamic values itself. Theological credo paced soar meet to the cultural dimension of society and resonate through the local knowledge (Fasya 2015).

Whenever the question arises where Islam is truly original, the answer is clearly no. All of Muslims in the world agreed that Islam as true merely referring to the figure of the Prophet Muhammad Peace be upon Him. Islam since the time of the Prophet has crossed struggle very long time. The dynamics of reality that kept identical during the $15^{\text {th }}$ Century was unstoppable covered life of his people. It thus reveals axiom symbiotic mutualism relation between Islamic texts and the reality of the people are inseparable. He therefore did 
not need to be cut down so that scattered disintegrating, even in the name of maintaining the authenticity of Islam though. In a landscape so, Islam Nusantara proper seat placed. A creative idea turns into the primary Islamic texts and legacy thinking of the scholars of the Salaf in the frame of the present dynamics (Iyubenu 2015).

\section{The Central Role of Walisongo}

The entry of Islam into the Nusantara's archipelago is often identified by the presence of the Walisongo. Many people believed that of Indonesian Islam they can be germinated and be a part of Indonesian life someday. Friendly Islam is not Islam shown as full anger; Islam shade and blend with tradition and local culture. So, to start this paper the author considers it necessary to write a piece of the chronology of the emergence of Walisongo start of the first generation.

Before the establishment of the Walisongo we know today as Sunan Bonang, Gunung Jati, Giri, etc. Kalidjaga turns out there have been nine trustees who are experts in certain fields. In the book Kanzul Ulum of Ibn Battuta is still stored in the Imperial Library Sultanate Ottoman Istanbul, the establishment Walisongo turned out the first time carried out by the Turkish Sultan Muhammad I, which receives reports from the merchants Gujarat (India) that in Java, the number of Muslims is still limited, based on these reports, Sultan Muhammad I formed a team of nine people:

Maulana Malik Ibrahim, came from Turkey, irrigation and governance experts,

Maulana Ishak, come from Disguise healer,

Maulana Ahmad Jumadil Kubro, originally from Egypt,

Maulana Muhammad Al Maghrobi, originally from Morocco,

Maulana Malik Isro'il, originally from Turkey, governance experts,

Maulana Muhammad Ali Akbar, originally from Iran, healer,

Maulana Hasanuddin, from Palestine,

Maulana Aliyuddin, from Palestine, and

Sheikh Subakir, from Iran, the expert community.

All of them can be called as the first batch of Walisongo, who came to the Javanese Island at the right time, since Majapahit was hit by the civil war (Paregreg War), so that their arrival was not so attention. Note that the first team of experts is not a religion or to say that they do not have enough knowledge of religion are qualified.

Maulana Malik Ibrahim as chairman of Walisongo died in 1419 A.D. then in the year 1421 A.D. posted a new Islamic propagator, named Ahmad Ali Rahmatullah of Champa is also the nephew of Maulana Ishak. He is a son of Abraham Asmarakandi which became law 
of Sultan Campha. Selection of Ahmad Ali Rahmatullah who is called as Raden Rahmat was a very appropriate decision. Therefore, Raden Rahmat considered having advantages (more in theology) and son Crown of Majapahit at the time was married to an aunt of Raden Rahmat.

In 1435 there were two people who died guardian, i.e. Maulana Malik Isro'il and Maulana Muhammad Ali Akbar. With the death of two people, the council filed a petition to the Sultan of Turkey (1421 Sultan Muhammad I was replaced by Sultan Murad II, who led until 1451) to send two people who have the ability to substitute a more profound religion.

The petition was granted and in 1436 sent two preachers. One of them Sayyid Jafar Shodiq, of Palestinian origin, who later settled in the Holy and known as Sunan Kudus. In the book Chronicle Demak (2001) Atmodarminto works, mentioned that Sayyid Ja 'far Shodiq is the only member who had the most Walisongo jurisprudence.

Their preacher was Syarif Hidayatullah of Palestinian origin who is an expert on war strategy. According to the "Babad Tanah Sunda Babad Cirebon" from PS Sulendraningrat, Syarif Hidayatullah was the grandson of King Siliwangi from Padjadjaran marriages Rara Santang and Sultan Syarif Abdullah of Egypt. Furthermore Syarif Hidayatullah settled in Cirebon and is known by the name of Sunan Gunung Jati.

With the arrival of young careers, it can be said that the composition of the board of trustees can we call the third generation. It appears from the above information that there were three young careers that certainly has the depth of knowledge of religion more than the previous generation. In 1462 two people died Walisongo members, namely Maulana Hasanuddin and Maulana Aliyuddin. Before that there were two trustee members who left the land of Java, namely Sheikh Subakir return to Persia and Maulana Ishak preaching in Pasai.

In the trial Walisongo in Ampeldenta (Surabaya), it was decided that there were four people who entered the council Walisongo, namely:

Raden Makhdum Ibrahim, son of Sunan Ampel who settled in the village of Bonang, Tuban. Hereinafter known as Sunan Bonang;

Raden Qosim, son of Sunan Ampel living in Lamongan and known as Sunan Drajat; Raden Paku, son of Maulana Ishaq who live in Gresik and to be known as Sunan Giri; Raden Mas Said, son of Duke Tuban living in Kadilangu, Demak. Hereinafter known as Sunan Kalijaga.

With these changes, the composition of the board of trustees can we call the fourth generation. In the councils of the fourth generation Walisongo are still two people who are from the first batch, so in 1463 they had served in Java for 59 years. Two men were Maulana Ahmad Jumadil Qubro who died in 1465 and Maulana Muhammad Al-Maghrobi (unknown 
year how his death).

In the Book of Walisana mentioned that at the time of Raden Fatah face Sheikh Siti Jenar, Maulana Muhammad Al Maghrobi still the central figure, the strong suspicion that he makes the decisions about the problem of Sheikh Siti Jenar. It should be noted that from the fourth generation of this many members Walisongo who was the son of the indigenous aristocracy. At the same time, the orientation of the teachings of Islam began to change from Islam Arabsentris be compromised (Indrayana, 2015).

Additionally, Moh. Adnan in his-(primbon) also mentioned that there are some other basic tasks of the Walisongo (may be called second generation) in addition to spread the religion of Islam, among them:

Sunan Ampel make Islamic regulations for the Java community,

King Pandhita in Gresik patterned batik fabric, woven striated and harness,

Sunan Majagung teaches treating a variety of foods, side dishes, renew farm tools and make pottery,

Sunan Gunung Jati in Cirebon teach ordinances praying and reciting mantras, method of treatment and procedures for clearing the forest,

Sunan Giri make government order in Java, set the calendar calculation cycle of change the day, month, year, tiger, adjust pawukon cycle, also initiated the opening of the road, Sunan Bonang science teaching mysticism, making the orchestra and how to change the rhythm of the gamelan,

Sunan Drajat teach the procedure to build a house, make a stretcher and palanquin,

Sunan Kudus teach how to make keris, equipment blacksmith, craft gold, also made a rule of law to the judicial system that is destined for the Javanese (Sunyoto 2011, 90-91).

From the explanation of the history of civilization can be seen that the archipelago is never separated from the process and the interaction between religion and cultural assimilation. Even in the past there has been a sublimation Walisongo paradigm from a previously Arabsentris into Islam typical of the archipelago. Thus no one if Karim was quoted as saying by Syarif Hidayatullah Islamic came to the conclusion that the Indonesian people are unique when compared to any Muslim community in the world. Islamic because they do not affect or change the practice of everyday life. In fact, the color of the locality is very much determining the pattern of Islamic society that would be encountered there were very affected region Sufi teachings, while others do not. So Islam for the Indonesian Muslim community is not a homogenous identity (Hidayatullah 2010, 17). 


\section{Finding the Truth:Text and Context}

There is one disease that hitherto has no cure: considers itself the most correct. In this case it is better if we recall at what has been said by Thomas Kuhn in his magnum opus, "The Structure of Scientific Revolution" (1962) as cited by Edi AH Iyubenu. In the book, Khun strike hard positivism so idolize "single truth". For Khun, all human beings are only capable of creating a "paradigm" the truth, not Face the Truth itself; could only reach a fact, not a reality (Iyubenu 2015, 13)

Then one of the causes of the "old-fashioned" also because so strong positivism in plugging the concept of truth in the minds of every modern society. Coupled with the understanding "sakralitas" excessive text, people suddenly become like God who simply condemned with glasses binary opposition: right and wrong, misguided-pious, and so on. This paradigm is coupled with the reality of Muslims in Indonesia.

"Sakralitas" on text or skriptual-textual understanding is misguided thought that was so dangerous. Ali Harb (a critical philosophical thinker of Lebanon) said that the people who talk a lot about books, the basic principles and the urgency of returning to the text sometimes it has to be the group most distant from the text. And could so they could not even grasp what is contained in it, including the nature and future generations who did not know, on the grounds that they are always in between words and object, between reality and concept as well as between the text and the event. (Harb 2012, 161).

The author does not intend doubt on the sanctity and authentity of Qur'an. But that should be understood that the verses of Qur'an largely uncharged teaching mujmal (global), not technically, by the nature of the mutashabihat paragraph (zhanniyyah, not qath'iyyah, a.k.a multi-interpretation), except for verses that pertained Ubudiah. Equally important to understand the nature of the decline there are verses in the Qur'an which is to respond to events, setting a new law and denied local laws/customs and nor vice versa, approve local laws/customs prevailing in Arabia at the time.

Evidence locality properties of the text of the Qur'an are verses about khamr, horse riding, and archery to slavery. The verse on the hijab stick out, for example, asbab al-nuzul occurs when Sauda (one of the wives of Muhammad.) Out of the house and meet with Umar bin Khattab, then he was reprimanded by Umar. Sauda later described the event to Muhammad and his being allowed out of the house for one interest. Then there came the verse that commands "stick out the veil" to be "different from the others" (as a distinguishing identity with indigenous slaves) and that "not bothered" by the hypocrites and polytheists at that time.

Thus, historically the Koran is "a response to the realities of the earth sky" Arab society at the time. This is the meaning of Qur'an as "cultural products"; created by God as a response 
to the dynamics of the past times in the span of more than 22 years. Therefore verses of Qur'an there is multi-interpretation, tend locality and belong to the realm muamalah, the hijab as subject was, for example, cannot be generalized and relevant applied in every country. (Iyubenu 2015, 46-47)

Another factor that contributed to the claim of truth is the uniformity of understanding between "Islamic law", "Syariah" and "Fikih/Jurisprudence". According to Said Aqil Siradj, in the context of Indonesia three things are often equated. Though substantially, all three there is a difference. Put simply Said Aqil Siradj describe that: Syariah is the main source of jurisprudence, i.e. legal texts are still contained in the Qur'an and Hadith, which in fact la yanthiqu (cannot say anything) unless otherwise human reason (understood by humans) as the operational conditions, while "Fikih" is the result of clerical understanding of the texts of law contained in the Qur'an and the Hadith (or so-called Syariah). As the understanding, of course fikih could be true it could be wrong and often different from one another due to differences in time and place. (Siradj 2015, 111)

It is also been expressed by Sahal Mahfudh about the concept of social fikih. For him, fikih should be able to display the dynamism and flexibility to deal with the social changes that speeding. Kiai Sahal Jurisprudence always aims that is the result of ijtihad is not rigid and sacred, but flexible and contextual. Decision of fikih at a certain time and place could have been considered valid are no longer relevant in the era or elsewhere. To illustrate this flexibility Kiai Sahal cites prank KH. Wahab Chasbullah: "pekih kuwi yen rupek diokoh yookoh" (fikh that if feels narrowing ya be loose). (Sahal 2015,29)

Derived from the description above, either Islamic law or fikih cannot necessarily be used as a pretext absolute to determine that this was wrong because it is the result of a review of existing human and temporal. In other words, the parameters truly one-in this contextrelative because arguably influenced by many factors particular place and time. So unethical if in the middle of the Indonesian nation heterogeneities such case used as a weapon to convict differences in perspective let alone the level of piety someone.

\section{Islam Nusantara: As the Middle Way?}

Ahmad Baso analogized that Islam Nusantara is like meeting featured two saplings of different types, but when put together in the process of crossing will generate a new seed is superior. Crosses Islam and the archipelago is required to obtain a new genius with characters or properties desired seed. These seeds will grow up healthy and can survive in any environment situation and clutches, tolerant and adaptive to the environment so they can grow large and healthy, do not wear out quickly, damaged or failed to grow. By crossing two different species it is expected that new species appear populist, the quality of a high civilization and resilient to various conditions and challenges and a new species that is called 
Islam Nusantara. So if we are absolutely sure of Islam Nusantara it is the result of crossing two of seeds, the more support the superiority of ijtihad turmeric natural wealth of our archipelago than, for example, import habbatussawda (black cumin). (Baso 2015, 55)

Therefore, it is not surprising that Imam Shafi'i, in his book the luminary, "al-Umm" as quoted by Ahmad Baso also stated that: "Ma min biladil-muslimina baladun wa illa-fihi 'ilmun qad shara ahluhu ila' ttibai qauli rajulin min ahlihi fi aktsari aqawilihi." In every country there is a science that Muslims lived and followed by its inhabitants and science that became the clerical grip in most opinion. It thus shows that geographical considerations into something important.

Greg Barton also had to reflect the core of Gus Dur in viewing Islam. According to Gus Dur, Islam is not static. The teachings of Islam is not something that is relegated once so and after that never require reformulation and reapplication. In other words, he argues that the essential characteristic of Islamic law is the necessity to be interpreted contextually. Because if the social and historical context changes, then change the application also eternal principles of the law;

"Call to the development and refreshment is not a solicitation to remodel Islamic law. Such an invitation is not just another Islamic law will put on the need for a moment, to the will of men who are always changing. That is an attempt to make it more sensitive to human needs today and in the future. With such sensitivity Islamic law will continue to make adjustments than necessary, without having to sacrifice the transcendental values predetermined by Allah. With that sensitivity, it can be Islamic law also gives its contribution to nation-building, which is to create values a dynamic life but based on the awareness of the necessity for humans to strive within the limits of his ability as a mere creature." (Fealy 1997, 176)

In addition, Azyumardi Azra assume that Islam Nusantara as represented by NU and Muhammadiyah have almost all the potential to advance to realize civilization rahmatan lil 'alamin. Capital is the amount of richness and diversity of institutions ranging from mosques, schools, madrasas, schools, universities, hospitals and clinics, homes for social sponsorship, cooperatives, to other economic activities. Consequently, many foreigners since the late 1980s, such as Fazlur Rahman Islam Nusantara looked great potential to stand the forefront in advancing the global Islamic civilization. With the Islamic civilization wasathiyah (middle way) Islam Nusantara can contribute more peaceful world civilization and harmony. Expectations like this, according Azyumardi Azra, increasing amid continuing conflict in the Muslim countries of the Arab world, South Asia, West Asia and Africa. To that end, NU and Muhammadiyah Islamic organizations along with other wasathiyah, not only need to improve thinking and charitable efforts in the country, but also to be more expansive spread Islam wasathiyah to foreign countries. Thus, Islam Nusantara able to stand at the forefront in realizing Islam as rahmatan lil 'alamin. (Azra, 2015) 


\section{Conclusion}

Islam Nusantara is not a form of movement to change the doctrine of Islam. It also did not going to move the Qiblat of Indonesian Muslims from Mecca to Indonesia. It just wanted to find a way how to anchor the culture of Islam in the context of a diverse society. Islam Nusantara just wants to show and display the face of Islam shady and welcoming not angry. By looking at the shards long history, Islam in Nusantara has experienced a long struggle with their diverse localities. He comes not to break or cut down the traditions and the local culture, but rather try to dialectic with the context in which it is located. Therefore flexibility nature, it is able to survive and thrive, so bring distinctive new Islamic expression and no one anywhere in the world.

Thus, Islam Nusantara is not exactly the new kinds of Islam but just wants to put something in place. With the presence of Islam Nusantara was a reminder that the Arab is not necessarily Muslim and that Islam is not necessarily Arab. With such a paradigm, that Islam Nusantara actually wanted to take out of the chaos cross orthodoxy in viewing religion, the classic debate that there was no tip base and naive who deny the truth of other things. With hope, the civilization of Islam Nusantara will become the world because Islamic civilization step treasures of science and Islamic values archipelago rahmatan lil 'alamin.

\section{References}

Ambary, Hasan Muarif. 2001. Menemukan Peradaban; Jejak Arkeologis dan Historis Islam Indonesia. Jakarta: Logos Wacana Ilmu.

Azra, Azyumardi. August 3, 2015. "Islam Indonesia Berkelanjutan". Opini Kompas.

Baso, Ahmad, 2015. Islam Nusantara Ijtihad Jenius dan Ijma’ Ulama Indonesia. Jakarta: Pustaka Afid.

Fasya, Teuku Kemal. August 4, 2015. "Dimensi Puitis dan Kultural Islam Nusantara”. Opini Kompas.

Fealy, Greg. 1997. Tradisionalisme Radikal: Persinggungan Nahdlatul Ulama-Negara, translation Ahmad Suaedy. Yogyakarta: LKIS.

Harb, Ali. 2012. Nalar Kritis Islam Kontemporer, translation Umar Bukhory. Yogyakarta: IRCISOD.

Hidayatullah, Syarif. 2010. Islam "Isme-Isme": Aliran dan Paham Islam di Indonesia. Yogyakarta: Pustaka Pelajar.

Indrayana, EA.. April 23, 2015.“Sejarah Walisongo dari Dokumen-Dokumen Terpercaya”. Duta Masyarakat.

Iyubenu, Edi AH. 2015. Berhala-Berhala Wacana: Gagasan Kontekstualisasi "Sakralitas Agama" secara Produktif-Kreatif. Yogyakarta: IRCISOD. 
Iyubenu, Edi AH. July 24, 2015. “Ontran-Ontran Islam Nusantara”. Opini Jawa Pos.

Sahal, Akhmad. 2015. Islam Nusantara Dari Ushul Fiqh hingga Paham Kebangsaan. Bandung: Mizan Pustaka.

Siroj, Said Aqil. 2015. Islam Sumber Inspirasi Budaya Nusantara Menuju Masyarakat Mutamaddin. Jakarta Pusat: LTN NU.

Sunyoto, Agus. 2011. Walisongo: Rekonstruksi Sejarah yang Disingkirkan, Jakarta: Transpustaka. 